\title{
Gender Differences in Children's Language: A Meta-Analysis of Slovenian Studies
}

LJUbica MarJanovič-UmeK ${ }^{\star 1}$ AND URŠKa FeKonja-Peklaj ${ }^{2}$

$\approx$ Child gender has been proved to affect toddlers'/children's language development in several studies, but its effect was not found to be stable across different ages or various aspects of language ability. The effect of gender on toddler's, children's and adolescents' language ability was examined in the present meta-analysis of ten Slovenian studies (nine cross-sectional studies and one longitudinal study). The ten studies were published between 2004 and 2016 and included a total of 3,657 toddlers, children and adolescents, aged from 8 months to 15 years. The language outcome measures refer to different aspects of language ability, including vocabulary, mean length of utterance, sentence complexity, language expression and comprehension, storytelling ability and metalinguistic awareness. Across the studies, language ability was assessed using different approaches and instruments, most of which were standardised on samples of Slovenianspeaking children. Based on the reported arithmetic means and standard deviations, the effect sizes of gender for each of the included studies were calculated, as well as the average effect size of gender across the different studies. The findings of the meta-analysis showed that the effect size of gender on toddlers'/children's/adolescents' language largely depended on their age and the aspect of language measured. The effect sizes increased with children's increasing age. All significant effects proved to be in favour of girls. The findings were interpreted in relation to the characteristics of language development and social cultural factors that can contribute to gender differences in language ability.

Keywords: meta-analysis, gender differences, language ability

1 * Corresponding Author. University of Ljubljana, Faculty of Arts, Department of Psychology, Slovenia; ljubica.marjanovic@ff.uni-lj.si.

2 University of Ljubljana, Faculty of Arts, Department of Psychology, Slovenia. 


\section{Razlike med spoloma v govoru otrok: Metaanaliza slovenskih študij}

Ljubica Marjanovič-Umek in URšKa Fekonja-Peklaj

$\approx$ Rezultati več raziskav so pokazali, da ima spol otroka pomemben učinek na govorni razvoj malčkov in otrok, vendar učinek spola ni stabilen prek različnih razvojnih obdobjih in za različne vidike govorne kompetentnosti. V tej metaanalizi smo preučevale_i učinek spola na govorno kompetentnost malčic_kov, otrok in mladostnic_kov. Vključevala je 10 slovenskih študij (devet izmed njih je bilo prečnih, ena pa je bila vzdolžna), ki so bile objavljene med letoma 2004 in 2016; skupno so vključevale 3.657 malčic_kov, otrok in mladostnic_kov, starih od 8 mesecev do 15 let. Mere govorne kompetentnosti v vključenih raziskavah so bile različne in so vključevale: velikost besednjaka, povprečno dolžino izjave, zapletenost stavkov, govorno izražanje in razumevanje, pripovedovanje zgodbe, metajezikovno zavedanje. Govorna kompetentnost je bila ocenjena $\mathrm{z}$ uporabo različnih pristopov in pripomočkov, izmed katerih je bila večina standardizirana na vzorcih slovensko govorečih otrok. $\mathrm{Na}$ podlagi aritmetičnih sredin in standardnih odklonov, dobljenih v posamezni raziskavi, sva izračunali velikost učinka spola za vsako izmed njih ter povprečno velikost učinka spola prek vseh raziskav. Rezultati metaraziskave so pokazali, da se je velikost učinka spola na govor malčic_kov, otrok, mladostnic_kov razlikovala glede na njihovo starost in glede na ocenjene mere govorne kompetentnosti. Velikost učinka je naraščala $\mathrm{z}$ naraščajočo starostjo otrok. Vsi pomembni učinki so bili v prid deklicam. Izsledke smo interpretirale_i v povezavi z značilnostmi govornega razvoja otrok in socialno-kulturnimi dejavniki okolja, ki lahko prispevajo $\mathrm{k}$ razlikam med spoloma $\mathrm{v}$ govorni kompetentnosti.

Ključne besede: metaanaliza, razlike med spoloma, govorna kompetentnost 


\section{Introduction}

Despite many studies in which authors have investigated the effect of gender on children's language across different developmental periods, and notwithstanding certain observed differences in language development of boys and girls, the reported findings do not allow one general conclusion in favour of either gender. Although the findings of several studies suggest a small but consistent effect of gender on early language development in favour of girls, the size of this effect depends both on the girls'boys' age and the aspect of language that was assessed (Bouchard, Trudeau, Sutton, Boudreault \& Deneault, 2009; Fenson et al., 1994; Simonsen, Kristoffersen, Bleses, Wehberg \& Jørgensen, 2014). Crawford (2001), for instance, argues that there are more similarities than differences between boys and girls in various aspects of their language ability.

Based on the assumption of the biological differences between males and females, research evidence shows that gender differences in language development to some extent reflect differences in the brain structure and function underlying language processes (e.g., Shaywitz et al., 1995), as well as differences in the speed of developmental processes (e.g., Huttenlocher, 1991). A number of functional imaging studies have reported a more bilateral pattern of activity during language processing in women compared to men (Wallentin, 2008). However, in their meta-analysis of 26 neuroimaging studies, Sommer and colleagues (Sommer, Aleman, Bouma \& Kahn, 2004) found that, although several of the studies, particularly those with smaller samples, showed gender differences in brain functioning, there was no significant effect of gender on language lateralisation either in children or adults.

On the other hand, several authors (e.g., Barbu et al., 2015; Bornstein et al., 2004; Lovas, 2011) emphasise the importance of socialisation factors in gender differences, such as parental expectations about gender roles and parents' and children's gender-specific behaviour. Wallentin (2008) argues that cultural explanations should also be taken into account when researching possible gender differences in language ability. Research evidence shows the important effect of the interaction between a child's gender and various factors of the social environment that can contribute to differences in the language ability of boys and girls. For instance, one of the contextual factors contributing to gender differences in language proved to be gender typing in parents' language with their children (e.g., Gleason, 1987; Leaper, Anderson \& Sanders, 1998). In their meta-analysis of studies comparing mothers' interactions with daughters versus with sons, Leaper and colleagues (Leaper et al., 1998) found that mothers tended to talk more and use more supportive speech with daughters than with sons. The differential use 
of language with either girls or boys by their parents might also be reflected in the difference in the type of words spoken by girls and boys, which was found in several studies (e.g., Stennes, Burch, Sen \& Bauer, 2005; Wehberg et al., 2008).

Research evidence also suggests that parents play differently with girls and boys, thus supporting their symbolic play and language to a different extent. For instance, Clearfield and Nelson (2006) found that, while there were no gender differences in infants' play behaviour (the frequency of initiating interaction with an adult and the direct responsiveness to mothers' verbal behaviour) at the age of 6-14 months, gender differences were found in mothers' verbal behaviour and level of engagement toward the child. The authors established that mothers interacted more with their daughters and made more interpretations and engaged in more conversation with them than with sons. On the other hand, mothers of sons made more comments and were more attentional, typified more by instructions than conversation. On a sample of 99 toddlers and children aged 1-5 years, Marjanovič-Umek and Fekonja-Peklaj (2017) found that parents used more symbolic transformations when playing with girls than with boys, thus providing more opportunities for the girls to engage in symbolic play, which is largely supported by the use of (meta)language and strongly related to more advanced language ability in children (e.g., Lyytinen, Poikkeus, \& Laakso, 1997).

\section{Boys' and girls' language across different age periods and various aspects of language ability}

There are a number of studies indicating a small but consistent female advantage in early language development (Wallentin, 2008). The findings of several studies (e.g., Berk, 1997; Bornstein \& Haynes, 1998; Bornstein, Haynes, O’Reilly \& Painter, 1996; Fenson et al., 1994; Eriksson et al., 2012) on gender differences in language development suggest that girls develop language faster than boys: girls are found to speak earlier, acquire the grammar of the language faster, use longer utterances and express a larger vocabulary throughout infanthood, toddlerhood and early childhood. In a study including 2,500 English-speaking toddlers aged 8-30 months, Fenson and colleagues (Fenson et al., 1994) found that girls were reported by their parents (using Communicative Development Inventories (CDI)) to use more communicative and symbolic gestures and to express a higher comprehensive and expressive vocabulary than boys. However, the authors emphasise that the gender differences were small, accounting only for 1-2 percent of the variance in language ability. In their research, which included ten studies and a sample of 13,783 non-English-speaking infants and toddlers, Eriksson and colleagues (Eriksson et al., 2012) found significant differences between girls and 
boys aged 8-30 months in their language ability, as assessed with $C D I$ (Fenson et al., 1994). The authors found that girls aged 8-16 months ${ }^{3}$ were reported by their parents to use more types of communicative gestures and more types of words than boys, although the effect size of gender was small. There were no significant gender differences in infants'/toddlers' comprehensive vocabulary. On a sample of older toddlers aged $16-30$ months, ${ }^{4}$ the authors found significant gender differences in word production (Eriksson et al., 2012). In a study including a sample of Swedish toddlers aged 8-24 months, Andersson and colleagues (Andersson et al., 2011) found small differences between boys and girls in their vocabulary size, appearing at the end of the second year. Their findings indicated that girls had a more even distribution of vocabulary scores, while boys had a wider range of scores. Furthermore, on a sample of two-year-old English-speaking twins, Galsworthy and colleagues (Galsworthy, Dionne, Dale \& Plomin, 200o) established that girls achieved higher scores in both verbal and non-verbal cognitive ability. However, the authors argue that gender only accounted for approximately 3 percent of the variance in toddlers' verbal ability and 1 percent of the variance in toddlers' non-verbal cognitive ability. In addition, boys generally achieved the highest and the lowest scores, while girls had the highest mean score. In their study, Bornstein and colleagues (Bornstein et al., 2004) established that, in the second through fifth year of age but not before or after, girls expressed a higher language ability than boys of the same age.

Apostolos and Napoleon (2001) argue that gender differences in vocabulary development are not constant across different ages. In their study of 162 Greek-speaking children aged 4-12 years, they found that girls tended to express a larger vocabulary than boys, but only at certain ages (for instance, they found no gender differences in vocabulary size between ages 4 and 5 , as well as between 11 and 12 years of age). According to several studies, however, the gender differences in language ability persist through childhood and adolescence (e.g., Golombok \& Fivush, 1994; Hedges \& Novell, 1995; Marjanovič-Umek, 2007): girls were found to read at an earlier age then boys, make fewer mistakes while reading, achieve higher scores in tests of written language, express a larger vocabulary and more advanced language comprehension, and achieve higher school grades in language than boys.

In their meta-analysis of 165 studies including samples of children and adults and measuring different aspects of language abilities (e.g., vocabulary, reading comprehension, verbal communication), Hyde and Linn (1988) found that 27 percent of the studies reported that females perform significantly better

3 Their language was assessed with CDI: Words and Gestures.

4 Their language was assessed with CDI: Words and Sentences. 
than males, while 66 percent reported no significant effect of gender on language ability and 7 percent reported males outperforming females. In spite of the small female advantage, Hyde and Linn (1988) argue that the size of the gender difference in language ability was small and could be considered to be zero.

\section{The aim of the study}

In recent years, several instruments for assessing language ability in Slovenian-speaking children of different ages have been developed. In line with the development of these instruments, which include language scales, parental questionnaires and semi-structured storytelling tests, several studies have been published analysing the characteristics of language development of Slovenianspeaking toddlers/children/adolescents, as well as establishing possible gender differences in their language ability. As the findings on gender effects on children's language are not consistent across different studies, a meta-analysis of ten different Slovenian studies was conducted in order to analyse the effect sizes of gender on the language ability of Slovenian-speaking children of different ages (infants, toddlers, children in early and middle childhood and adolescents). The present study represents the first meta-analysis of gender differences carried out on Slovenian speaking samples.

\section{Method}

\section{Retrieval of studies}

The studies used in the present meta-analysis were quantitative studies in which gender differences in language ability were assessed on independent samples of Slovenian-speaking children. The studies were published in scientific journals or monographs between 2004 and 2016. The criteria for the retrieval of the studies were that the effect size of gender on child language ability could be calculated from the reported findings and that the language ability was assessed using an objective, valid and reliable measure. Only studies with the normative samples of children were included.

Thus, ten studies were selected, including a total of 3,657 Slovenianspeaking children of different ages (from 8 months to 15 years). The children's language ability was assessed using various instruments, all of which were designed for or adapted to the Slovenian language: Communicative Development Inventory: Words and Sentences (CDI: Words and Sentences) and Communicative Development Inventory: Words and Gestures (CDI: Words and Gestures) 
(Marjanovič-Umek, Fekonja-Peklaj, Sočan \& Komidar, 2011a); Storytelling Test: Glove (STT: Glove) (Marjanovič-Umek et al., 2011b); Test of General Language Ability: Written Language (TGLA-WL) (Marjanovič-Umek et al., 2011c); Scales of General Language Development - LJ (SGLD - LJ) (Marjanovič-Umek, Fekonja, Podlesek, Kranjc \& Bajc, 2008); Language Development Scale (LDS) (MarjanovičUmek \& Fekonja, 2006); Test of Written Language - Third Edition (TOWL-3) (Hammill \& Larsen, 1996); Storytelling by a Wordless Picture Book (MarjanovičUmek, Fekonja \& Kranjc, 2004). Within the selected studies, various aspects of language ability were assessed (e.g., vocabulary, mean length of utterance, sentence complexity, storytelling ability, general language ability) using different assessment approaches (e.g., parental reports, standardised language scales, semistructured storytelling test).

\section{Calculation and interpretation of effect sizes}

The effect size $d$ was calculated by dividing the difference between the male and female means by the pooled within-sex standard deviation (Cohen, 1977).

$$
\frac{M(\text { girls })-M(\text { boys })}{S D(\text { polled })}
$$

Positive $d$ values indicated girls' higher language ability and negative $d$ values indicated boys' higher language ability. Effect sizes of $0.20,0.50$ and 0.80 were interpreted as small, medium and large effects, respectively, based on Cohen (1977). Effect size of 0.15 was interpreted as very small and effect sizes smaller than 0.15 were interpreted and negligible. The total effect size was calculated across all ten studies.

\section{Results and discussion}

Effect sizes (Cohen's $d$ ) were calculated for each of the collected studies. Thus, 28 effect sizes were calculated within the ten studies, relating to the different measures of language ability and different age groups included in the studies. The sample sizes, children's age, instruments used and language ability measured in each separate study are shown in Table 1. 
Table 1. Effect sizes of gender on language ability in the selected studies.

\begin{tabular}{|c|c|c|c|c|c|c|c|}
\hline Study & $\mathrm{N}$ & $\begin{array}{c}N \\
(M)\end{array}$ & $\begin{array}{l}N \\
(F)\end{array}$ & Age & Instrument & Language ability & $d$ \\
\hline $\begin{array}{l}\text { Marjanovič-Umek, } \\
\text { Fekonja-Peklaj, Sočan }\end{array}$ & 152 & 72 & 80 & $8-16 m$ & CDI: Words and Gestures & Vocabulary (c) & 0.00 \\
\hline \& Komidar (2011a) & 358 & 186 & 172 & $16-30 \mathrm{~m}$ & CDI: Words and Sentences & $\begin{array}{l}\text { Vocabulary (e) } \\
\text { SC }\end{array}$ & $\begin{array}{l}0.00 \\
0.00\end{array}$ \\
\hline $\begin{array}{l}\text { Marjanovič-Umek, } \\
\text { Fekonja, Kranjc \& Bajc } \\
\text { (2008) }\end{array}$ & 953 & 457 & 496 & $16-30 m$ & CDI: Words and Sentences & $\begin{array}{l}\text { Vocabulary (e) } \\
\text { MLU } \\
\text { SC }\end{array}$ & $\begin{array}{l}0.27^{*} \\
0.34^{*} \\
0.40^{*}\end{array}$ \\
\hline $\begin{array}{l}\text { Marjanovič-Umek, Fe- } \\
\text { konja-Peklaj, Podlesek } \\
\text { \& Kranjc (2011) }\end{array}$ & 83 & 45 & 38 & $16-30 m$ & CDI: Words and Sentences & $\begin{array}{l}\text { Vocabulary (e) } \\
\text { MLU } \\
\text { SC }\end{array}$ & $\begin{array}{l}0.00^{*} \\
0.01 \\
0.00\end{array}$ \\
\hline $\begin{array}{l}\text { Marjanovič-Umek, } \\
\text { Božin, Čermak, Štiglic, } \\
\text { Bajc \& Fekonja-Peklaj } \\
\text { (2016) }\end{array}$ & 51 & 28 & 23 & $31 \mathrm{~m}$ & CDI: Words and Sentences & $\begin{array}{l}\text { Vocabulary (e) } \\
\text { MLU } \\
\text { SC }\end{array}$ & $\begin{array}{l}0.00 \\
0.05 \\
0.18\end{array}$ \\
\hline $\begin{array}{l}\text { Marjanovič-Umek, } \\
\text { Fekonja, Podlesek, } \\
\text { Kranjc \& Bajc (2008) }\end{array}$ & 494 & 245 & 249 & $2-6 y$ & $S G L D-L J$ & $\begin{array}{l}\text { Language comprehension } \\
\text { Language expression } \\
\text { Metalinguistic } \\
\text { awareness }\end{array}$ & $\begin{array}{l}0.00 \\
0.00 \\
0.00\end{array}$ \\
\hline $\begin{array}{l}\text { Fekonja, Marjanovič- } \\
\text { Umek \& Kranjc (2005) }\end{array}$ & 80 & 41 & 39 & $3-4 y$ & LDS & General language ability & 0.05 \\
\hline $\begin{array}{l}\text { Marjanovič-Umek, } \\
\text { Fekonja-Peklaj \& } \\
\text { Podlesek (2010) }\end{array}$ & 156 & 85 & 71 & $3-6$ y & STT & $\begin{array}{l}\text { Vocabulary (e) } \\
\text { MLU } \\
\text { Number of events } \\
\text { Mental states }\end{array}$ & $\begin{array}{l}0.01^{*} \\
0.03 \\
-0.01 \\
0.09\end{array}$ \\
\hline $\begin{array}{l}\text { Marjanovič-Umek, } \\
\text { Fekonja \& Kranjc } \\
\text { (2004) }\end{array}$ & 123 & 60 & 63 & $4 ; 3-9 ; 3$ y & $\begin{array}{l}\text { Storytelling by a Picture } \\
\text { Book }\end{array}$ & $\begin{array}{l}\text { Story coherence } \\
\text { Story cohesion }\end{array}$ & $\begin{array}{l}0.20 \\
0.06\end{array}$ \\
\hline $\begin{array}{l}\text { Marjanovič-Umek, } \\
\text { Fekonja-Peklaj, Sočan } \\
\text { \& Komidar (2011b) }\end{array}$ & 310 & 150 & 160 & $8-14 y$ & $T G L A-W L$ & General language ability & $0.84^{*}$ \\
\hline \multirow[t]{2}{*}{$\begin{array}{l}\text { Marjanovič-Umek, } \\
\text { Kranjc, Fekonja \& Bajc } \\
\text { (2007) }\end{array}$} & 127 & 60 & 67 & $4 ; 9-6 ; 3$ y & $S G L D-L J$ & $\begin{array}{l}\text { Language comprehension } \\
\text { Language expression } \\
\text { Metalinguistic awareness }\end{array}$ & $\begin{array}{l}0.20 \\
0.53 \\
0.20\end{array}$ \\
\hline & $\begin{array}{l}358 \\
412\end{array}$ & $\begin{array}{l}179 \\
198\end{array}$ & $\begin{array}{l}179 \\
214\end{array}$ & $\begin{array}{l}9 y \\
15 y\end{array}$ & $\begin{array}{l}\text { TOWL-3 } \\
\text { TOWL-3 }\end{array}$ & $\begin{array}{l}\text { General language ability } \\
\text { General language ability }\end{array}$ & $\begin{array}{l}0.56^{*} \\
1.03^{*}\end{array}$ \\
\hline
\end{tabular}

Note. ${ }^{*}$... significant gender differences between girls and boys were found in the study (by t-test or ANOVA); $d$... Cohen's $d$; m... months; $y . .$. years; $N(M)$... number of males included in the study; $N(F)$... number of females included in the study. MLU... mean length of utterance; SC... sentence complexity; Vocabulary (c)... comprehensive Vocabulary; Vocabulary (e)... expressive Vocabulary. The studies are presented by the increasing age of the sample.

The effect sizes within the different studies ranged from no effect $(d=$ o.0o) to a large effect $(d=1.03)$ of gender on different aspects of children's language ability. Negligible or zero effect sizes were found in seven studies that included infants, toddlers and children in early childhood, relating to 17 measures 
of language ability (e.g., comprehensive and expressive vocabulary, MLU and sentence complexity, storytelling ability). Very small effect sizes were found in one study in favour of girls, relating to sentence complexity as assessed by their parents at 31 months, while small effect sizes were found in three studies, all in favour of girls, relating to 6 measures of language ability (e.g., vocabulary, MLU, story coherence, language comprehension). Medium to large effect sizes were found in two studies, relating to general language ability, as assessed by written communication and language expression. All of these were found in samples of children and adolescents aged from 4;9 to 15 years, and were all positive, indicating that girls expressed higher language ability than boys.

In the next step, we calculated the average effect size across all of the studies. The total $d$ was 0.18 , indicating a small effect size of gender on language ability across all of the studies in favour of girls. As presented in Figure 1, the majority of effect sizes were close to zero, indicating a negligible effect of gender on children's language or no effect at all. The increase of the effect sizes of gender with children's age is also evident from Figure 1.

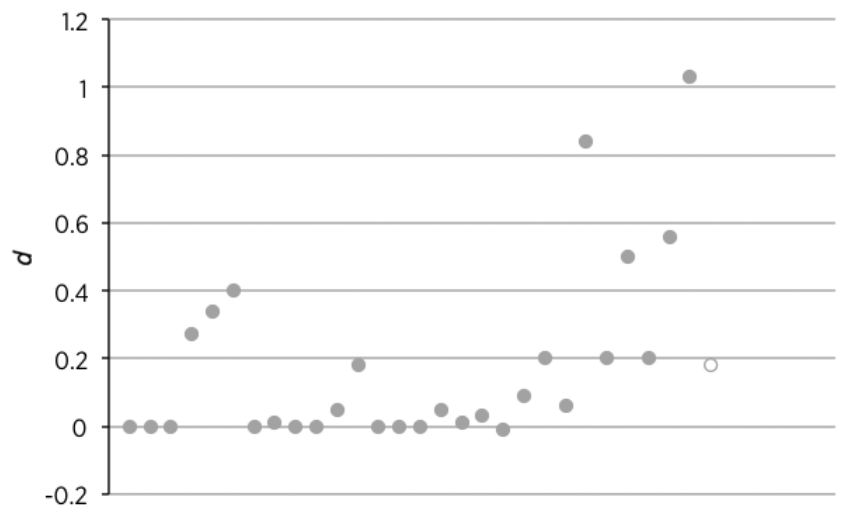

Note. $d$ values are presented in the same order as in Table 1. The effect sizes calculated within the selected studies are shown in black; the total effect size calculated across studies is shown in white.

Figure 1. Graphical representation of the effect sizes of gender on toddlers'/ children's/adolescents' language ability across the ten selected studies.

The findings do not allow a single general conclusion about the effect of gender on language ability in favour of either boys or girls, as it seems that the effect size of gender largely depends on the age of the children and the aspect of language ability measured.

Similar to several other studies (e.g., Bornstein et al., 2004; Hyde \& Linn, 
1988), it was found that gender differences in children's language ability were not consistent across the ten studies. In fact, the calculated effect sizes ranged from none to high and depended on the age of the sample as well as on the language ability being assessed. In the studies that included infants and toddlers, the effect sizes were mostly negligible, very small or small (on the samples of infants and toddlers aged 8-30 months, where vocabulary, sentence complexity and MLU were assessed by parents using $C D I$, and on the samples of children aged 2-6 years, where the cohesion of their stories and their general language ability were assessed using a semi-structured storytelling test and standardised scales of language). Although research evidence shows that gender differences exist in the early language ability of infants and toddlers (e.g., Eriksson et al., 2012; Fenson et al., 1994), we found that the effect sizes were either small, very small or close to zero. Our findings showed that the largest effect sizes of gender were typical for the studies that included large samples of children in late childhood and adolescents, aged 8-15 years, where their general language ability was assessed by their written language ability. A medium effect size was also found in a study that included children aged 4- 6 years and measured their language expression. These findings are in line with studies in which authors establish significant gender differences in the language ability of children in early and middle childhood, as well as in adolescents (e.g., Apostolos \& Napoleon, 2001; Hedges \& Novell, 1995; Marjanovič-Umek, 2007).

All significant effects, whether small or large, were found in favour of girls, suggesting that girls expressed a higher language ability than boys at different ages and regarding different aspects of language. In this respect, our findings are similar to those of Hyde and Linn (1988), who established that the majority of significant gender differences found in their meta-analysis were in favour of girls. The authors did, however, report that males outperformed females in 7 percent of the studies included in their meta-analysis, while the present study found no significant effects of gender on language ability in favour of boys. It should be noted that the number of studies included in our meta-analysis was small, and that several of the studies included small samples of children. We should therefore be cautious in drawing general conclusions about gender differences in language ability based on our findings.

In general, our findings support those of several other authors who argue that although gender differences in early language ability exist, they are predominantly small and account for a small share of variance in children's language (e.g., Fenson et al., 1994; Galsworthy et al., 2000). In addition, the average effect size calculated across all of the studies was small and in favour of girls; the majority of effect sizes were close to zero, thus supporting Crawford's (2001) thesis that 
more similarities than differences exist between boys and girls in their language ability. On the other hand, it seems that the effect sizes of gender on language ability increased with the age of children included in the studies, suggesting that the gender differences in early language ability, which proved to be rather small, increased throughout childhood and adolescence. In our meta-analysis, we did not consider the effects of social factors on children's language development and possible gender differences, but the findings of several studies suggest that such effects should be taken into account when interpreting the effect of gender on children's language ability (e.g., Barbu et al, 2015; Gleason, 1987; Wallentin, 2008). Both parents, preschool teachers and school teachers all play an important role in supporting the language ability of both boys and girls across different developmental periods and may increase the gender differences in language ability with their differential behaviour towards boys and girls. Several studies suggest that parents talk differently with boys and girls (e.g., Gleason, 1987; Leaper et al., 1998), thus providing different learning environments for them to develop their language and possibly increasing the existing gender differences in language ability. With the increasing gender differences in language ability found in our study, special emphasis should be placed on providing efficient support for boys' language development both within the family as well as within different levels of the school system, while encouraging girls to develop their language, as well.

\section{Conclusions}

The findings of our meta-analysis in general indicate small gender differences in language ability, which, however, increase with children's increasing age. One important finding, which also contributes to the research field, is that gender differences depend on the aspect of language ability being measured (e.g., the largest gender differences were found in the oldest samples of children and adolescents with written language as a measure of language ability). In our opinion, special emphasis should be placed on providing equal opportunities and support for language development of both genders, both in the home environment as well as within institutions (e.g., preschools, primary and secondary schools), so that the small gender differences in early language ability are not multiplied and increased throughout the child's development and influenced by stereotypical differential behaviour and implicit theories of adults. 


\section{References}

Apostolos, E., \& Napoleon, M. (2001). Word-meaning development in Greek children's language: The role of children's sex and parents educational level. Presented at Xth European Conference on Developmental Psychology, Uppsala.

Barbu, S., Nardy, A., Chevrot, J.-P., Guellaï, B., Glas, L., Juhel, J., \& Lemasson, A. (2015). Sex differences in language across early childhood: Family socioeconomic status does not impact boys and girls equally. Frontiers in Psychology, 6, 1874. http://doi.org/10.3389/fpsyg.2015.01874. Berk, L. E. (1997). Child development. Illinois: Allyn and Bacon.

Bornstein, M. H., \& Haynes, O. M. (1998). Vocabulary competence in early childhood: Measurement, latent construct, and predictive validity. Child Development, 69(3), 654-671.

Bornstein, M. H., Cote, L. R., Maital, S., Painter, K., Par, S.-Y., Pascual L., Pêcheux, M.-G., Ruel, J., Venuti, P., \& Vyt, A. (2004). Cross-linguistic analysis of vocabulary in young children: Spanish, Dutch, French, Hebrew, Italian, Korean, and American English, Child Development, 75(4), 1115-1139. Bornstein, M. H., Haynes, O. M., O’Reilly, W. A., \& Painter, K. M. (1996). Solitary and collaborative pretence play in early childhood: Sources of individual variation in the development of representational competence. Child Development, 67(6), 2910-2929.

Bouchard, C., Trudeau, N., Sutton, A., Boudreault, M.-C., \& Deneault, J. (2009). Gender differences in language development in French Canadian children between 8 and 30 months of age. Applied Psycholinguistics, 30(4), 685-707.

Clearfield, M. W., \& Nelson, N. M. (2006). Sex differences in mothers' speech and play behavior with 6-, 9-, and 14-month-old infants. Sex Roles, 54(1/2), 127-137.

Cohen, J. (1977). Statistical power analysis for the behavioral sciences. New York, NY: Routledge. Crawford, M. (2001). Gender and language. In R. K. Unger (Ed.), Psychology of women and gender (pp. 228-244). New York: John Wiley and Sons, Inc.

Eriksson, M., Marschik, P. B., Tulviste, T., Almgren, M., Pereira, M. P., Wehberg, S., MarjanovičUmek, L., Gayraud, F., Kovačevič, M., \& Gallego, C. (2012). Differences between girls and boys in emerging language skills: Evidence from 10 language communities. British Journal of Developmental Psychology, 3o(2), 326-343.

Fekonja Peklaj, U., Marjanovič Umek, L., \& Kranjc, S. (2005). Otrokov govorni razvoj v povezavi z njegovim spolom in izobrazbo staršev [Language development in early childhood in relation to child's gender and parental education]. Psihološka obzorja, 14(1), 53-79.

Fenson, L., Dale, P. S., Reznick, J. S., Bates, E., Thal, D., \& Pethick, S. (1994). Variability in early communicative development. Monographs of the Society for Research in Child Development, 59(5), $174-185$.

Galsworthy M. J., Dionne G., Dale P. S. \& Plomin R. (2000). Sex differences in early verbal and nonverbal cognitive development. Developmental Science, 3(2), 206-215.

Gleason, J. B. (1987). Sex differences in parent-child interaction. In S. U. Philips, S. Steele \& C. Tanz (Eds.), Language, gender, and sex in comparative perspective (pp. 189-199). Cambridge: University Press. 
Golombok, S., \& Fivush, R. (1994). Gender development. Cambridge: University Press.

Hammill, D. D., \& Larsen, S. C. (1996). Test of Written Language-3 (TOWL-3). Austin, TX: ProEd, Inc.

Hedges, L. V., \& Nowell, A. (1995). Sex differences in mental test scores, variability, and numbers of high-scoring individuals. Science, 269(5220), 41-45.

Huttenlocher, J., Haight, W., Bryk, A., Seltzer, M., \& Lyons, T. (1991). Early vocabulary growth: Relation to language input and gender. Developmental Psychology, 27(2), 236-248.

Hyde, J. S., \& Linn, M. C. (1988). Gender differences in verbal ability: A metaanalysis. Psychological Bulletin, 104(1), 53-69.

Leaper, C., Andersson, K., \& Sanders, P. (1998). Moderators of gender effects on parents' talk to their children: A meta-analysis. Developmental Psychology, 34(1), 3-27.

Lovas, G. S. (2011). Gender and patterns of language development in mother-toddler and fathertoddler dyads. First Language, 31(1), 83-108.

Lyytinen, P., Poikkeus, A.-M., \& Laakso, M.-L. (1997). Language and symbolic play in toddlers. International Journal of Behavioral Development, 21(2), 289-302.

Marjanovič Umek, L. (2007). Diferenciacija v šoli: enako ali različno za različne otroke

[Differentiation in school: The same or different for different children]. Sodobna pedagogika, $58(2)$, 108-127.

Marjanovič Umek, L., Božin, N., Čermak Hauko, N., Štiglic, N., Bajc, S., \& Fekonja Peklaj, U. (2016). Early language development: Vocabulary comparison of Slovenian boys and girls. Sodobna pedagogika, 67(1), 12-36.

Marjanovič-Umek, L., \& Fekonja-Peklaj, U. (2017). The role of child gender and parental knowledge of child development in parent-child interactive play. Sex Roles, 1-14. doi: 10.1007/s11199-016-0734-7. Marjanovič Umek, L., Fekonja Peklaj, U., \& Kranjc, S. (2004). Pripovedovanje zgodbe kot pristop za ugotavljanje otrokovega govornega razvoja [Storytelling as an approach to evaluate the child's level of speech development]. Psihološka obzorja, 13(1), 43-64.

Marjanovič Umek, L., Fekonja Peklaj, U., Kranjc, S., \& Grgić K. (2008). The effect of children’s gender and parental education on toddler language development. European Early Childhood Education Research Journal, 16(3), 325-342.

Marjanovič Umek, L., Fekonja Peklaj, U., \& Podlesek, A. (2010). Razvoj pripovedovanja zgodbe v zgodnjem otroštvu [The development of storytelling in early childhood]. Psihološka obzorja, 19(4), 35-53.

Marjanovič Umek, L., Fekonja Peklaj, U., Podlesek, A., \& Kranjc, S. (2011). Assessing toddler language ability: Agreement of parents' and preschool teachers' assessments. European Early Childhood Education Research Journal, 19(1), 21-43.

Marjanovič Umek, L., Fekonja Peklaj, U., Podlesek, A., Kranjc, S., \& Grgić K. (2008). Lestvice splošnega govornega razvoja - LJ: (LSGR - LJ): priročnik [Scales of General Language Development LJ: Manual.]. Ljubljana: Center za psihodiagnostična sredstva.

Marjanovič Umek, L., Fekonja Peklaj, U., Sočan, G., \& Komidar L. (2011a). Ocenjevanje sporazumevalnih zmožnosti dojenčkov in malčkov: Lista razvoja sporazumevalnih zmožnosti: 
besede in geste, Lista razvoja sporazumevalnih zmožnosti: besede in stavki [Assessing infants' and toddlers' communication skills: Communicative Development Inventory: Words and Gestures, Communicative Development Inventory: Words and Sentences]. Ljubljana: Center za psihodiagnostična sredstva.

Marjanovič Umek, L., Fekonja Peklaj, U., Sočan, G., \& Komidar L. (2011b). Splošni govorni preizkus, pisno sporočanje : SGP-PS [Test of General Language, Written Communication]. Ljubljana: Center za psihodiagnostična sredstva.

Marjanovič-Umek, L., Fekonja-Peklaj, U., Sočan, G., \& Komidar, L. (2011c). Preizkus pripovedovanja zgodbe [Storytelling Test]. Ljubljana: Center za psihodiagnostična sredstva.

Marjanovič Umek, L., Kranjc, S., Fekonja Peklaj, U., \& Grgić K. (2007). Govor deklic in dečkov [Language of girls and boys]. Razprave, 20, 115-131.

Shaywitz, B. A., Shaywitz, S. E., Pugh, K. R., Constable, R. T., Skudlarski, P., Fulbright, R. K., et al. (1995). Sex differences in the functional organization of the brain for language. Nature, 373(6515), 607-609.

Simonsen, H. G., Kristoffersen, K. E., Bleses, D., Wehberg, S., \& Jørgensen, R. N. (2014). The Norwegian Communicative Development Inventories: Reliability, main developmental trends and gender differences. First Language, 34(1), 3-23.

Sommer, I. E. C., Aleman, A., Bouma, A., \& Kahn, R. S. (2004). Do women really have more bilateral language representation than men? A meta-analysis of functional imaging studies. Brain, 127(8), $1845-1852$.

Stennes, L. M., Burch, M. M., Sen, M. G., \& Bauer, P. J. (2005). A longitudinal study of gendered vocabulary and communicative action in young children. Developmental Psychology, 41(1), 75-88. Wallentin, M. (2008). Putative sex differences in verbal abilities and language cortex: A critical review. Brain \& Language, 108(3), 175-183.

Wehberg, S., Vach, W., Bleses, D., Thomsen, P., Madsen, T. O., \& Basboll, H. (2008). Girls talk about dolls and boys about cars? Analyses of group and individual variation in Danish children's first words. First Language, 28(1), 71-85. 


\section{Biographical note}

LJUbica Marjanovič-Umek, $\mathrm{PhD}$, is a full professor, employed at University of Ljubljana, Faculty of Arts, Department of Psychology. She is a developmental psychologist, researching mainly in the fields of early language and cognitive development, development of early literacy and play, family literacy, psychology of gender as well as the quality of preschool and the transition into primary school. She is a co-author of several instruments for assessing different areas of child's language and literacy development.

UrŠKa Fekonja-PeklaJ, $\mathrm{PhD}$, is an assistant professor employed at University of Ljubljana, Faculty of Arts, Department of Psychology. She is a developmental psychologist and her main areas of research include early language and literacy development, development of play, the quality of preschool and family literacy. She is a co-author of several Slovenian instruments for assessing child's language development. 